\title{
Antibacterial and Washing Resistance Improvement of Cotton Fabric Using Some Metal Oxides
}

\author{
Aslihan Koruyucu $^{1}$ (D) 0000-0002-8443-5188 \\ Berna Erdal $^{2}$ (iD) 0000-0003-3375-7926 \\ Mine Aydın Kurç² iD 0000-0002-5053-4276 \\ Dumrul Gülen ${ }^{2}$ (D) 0000-0002-8711-7820 \\ ${ }^{1}$ Department of Textile Engineering, Namık Kemal University, Çorlu/TEKIRDAG \\ ${ }^{2}$ Department of Medical Microbiology,Namık Kemal University, Süleymanpaşa/TEKIRDAG
}

Corresponding Author: Aslıhan Koruyucu, adelituna@nku.edu.tr.

\begin{abstract}
$\mathrm{Cu}_{2} \mathrm{O}, \mathrm{CuO}, \mathrm{ZnO}$-microparticles with different size and morphology directly influences their antimicrobial potential. In this study, the possible improvement of the antibacterial and washing resistance up to 20 washing cycles performance of $100 \%$ cotton fabrics were investigated. At high temperatures, carboxylic acids form ester-type crosslinking with cellulose molecules and provide antibacterial activity. For this purpose, carboxylic acids such as BTCA and CA were used in this study.The purpose of this research was to evaluate 1,2,3,4-butantetracarboxylic acid (BTCA) and citric acid monohydrate (CA) as an crosslinking agent for washing resistance of $100 \%$ cotton textile substrates against, Staphylococcus aureus (ATCC 43300), Bacillus subtilis (NRRL NRS-744), Escherichia coli (ATCC 35218) and Klebsiella pneumoniae (ATCC 70063). Cupper oxide and zinc oxide were assimilated in the coating bath for the antibacterial property. BTCA concentration in the solutions influenced the antibacterial and washing properties of the cotton fabrics. The Fourier Transform Infra-Red -Attenuated Total Reflection (FTIR-ATR) spectra showed a new summit that confirmed the ester linkage formation and crosslinking reaction for application.
\end{abstract}

\section{ARTICLE HISTORY}

Received: 21.04.2020

Accepted: 28.01.2021

\section{KEYWORDS}

Antibacterial, cotton fabric, copper oxide, zinc oxide, washing resistance.

\section{INTRODUCTION}

Novel materials, including textiles for specific applications have to satisfy consumers' growing demands. Due to various applications, clothing and also economic aspects, it is necessary for a material to perform several functions. Intensive development of nanotechnology in the area of micro- and nano-structure generation offers the possibility of creating novel textile materials with protective properties for human beings and for their natural environment.

Nanoparticles (NPs) of some metal-oxides such as copper(I)oxide $\left(\mathrm{Cu}_{2} \mathrm{O}\right)$ and zinc $(\mathrm{ZnO})$ belong to a group of compounds with antibacterial properties.

The usage of nanoparticles, as new agents for inhibition of microbial growth, has developed due to the development of antibiotic resistance ${ }^{1-3}$. The particle with $1-100 \mathrm{~nm}$ size that behaves as a whole unit with respect to transport and properties is called nanoparticle ${ }^{4-6}$. These particles which have much higher surface area than conventional materials are currently considered as antimicrobial agents ${ }^{1}$. Among these nano-materials, nano-metals, such as copper and zinc oxide have been used more because of their less toxicity ${ }^{7-8}$. The copper and zinc oxide micro and NPs were studied in most related research, exhibiting antibacterial effect at low concentrations.

Ionic nanoparticulate metal oxides are among the potentially interesting antimicrobial agents because of their extremely high surface areas and special crystalline structures with high number of edges and corners and other reactive sites ${ }^{9}$. Copper oxide nanoparticle ( $\left.\mathrm{CuO} \mathrm{NP}\right)$ is the simplest member of the $\mathrm{Cu}$ compounds that reveal a range of potential physical properties and is much cheaper than silver oxide. It can be mixed easily with polymers to provide composites with unique physio-chemical

To cite this article: Koruyucu A, Erdal B, Kurç MA, Gülen D. 2021. Antibacterial and Washing Resistance Improvement of Cotton Fabric Using Some Metal Oxides, Tekstil ve Konfeksiyon, 31(1), 19-26. 
properties. Also, these CuONPs have high surface areas and special crystalline structures to give antimicrobial activity that is application dose dependent ${ }^{10}$.

Metal ions, e.g. silver (Ag) ${ }^{11}$, zinc $(\mathrm{Zn})^{12}$ and copper $(\mathrm{Cu})$ 13-14 exhibit strong antibacterial activity. For a long time, the antimicrobial properties of $\mathrm{Ag}$ have been known, which are very useful both in the textile industry and in medicine ${ }^{1-6}$ ${ }^{, 15}$. In recent years many examples of antibacterial activity of $\mathrm{Zinc}$ oxide $(\mathrm{ZnO})^{8-10,16-18}$. Titanium oxide $\left(\mathrm{TiO}_{2}\right)$ and other metal oxides have been described in literature ${ }^{18-23}$. It was demonstrated that the highest activity against bacteria was exhibited by Ag nanoparticles (NPs) with dimensions of 1$10 \mathrm{~nm}^{24}$ and also by $\mathrm{TiO}_{2}$ NPs with dimensions of below $20 \mathrm{~nm}^{25}$.

Copper oxide also has good antibacterial, antiviral and antifungal properties ${ }^{26-31}$. Although small concentrations of $\mathrm{CuO}$ are sufficient, quite often, higher doses are used to inhibit the growth of certain microorganisms and achieve bactericidal activity ${ }^{32}$. Permanent biocidal properties of textiles containing 3-10\% of $\mathrm{CuO}$ were described. In recent years, new antibacterial materials based on CuONPs have been developed ${ }^{14,33-35}$.

As potential novel antibacterial agents, metal oxide nanoparticles like $\mathrm{CuO}$ and $\mathrm{ZnO}$ are being thoroughly investigated. Their relatively low toxicity against human cells ${ }^{36}$, low $\operatorname{cost}^{37}$, size-dependent effective inhibition against a wide range of bacteria, ability to prevent biofilm formation ${ }^{38}$ and even eliminate spores $^{39}$ make them suitable for application as anti-bacterial agents in the fabric ${ }^{38}$, skincare products $^{40}$, biomedical $^{41}$ and food-additive industries ${ }^{42}$.

$\mathrm{CuO}$ and $\mathrm{ZnO}$, being constituted by essential elements, are more biocompatible than other metal oxides and their toxicity is lower than, for example, silver- or nickel-based $\mathrm{NPs}^{43-46}$.

Since nanoparticular passes from cell to cell by passing the semi-permeability control mechanism of the cells, their us for health is unfavorable. For this reason, micro copper (I), copper(II) and zinc oxide particles were used in this study.

$\mathrm{Cu}_{2} \mathrm{O}$ was used in this research because of its better antibacterial properties ${ }^{47}$. Therefore, in our study basis and below $5 \mu \mathrm{m}$ particles copper (I) oxide, below $10 \mu \mathrm{m}$ particles copper(II)oxide and below $5 \mu \mathrm{m}$ particles zinc oxide were used for antibacterial activity and antibacterial effect was assesment after repeated washings (1-3-5-7-1013-15-17-20).

The BTCA (1,2,3,4-butantetracarboxylic acid) and CA (citric acid) were used as crosslinking agents to hold $\mathrm{CuO}$, $\mathrm{Cu}_{2} \mathrm{O}$ and $\mathrm{ZnO}$ particles on cotton fabric to obtain antimicrobial properties with high washing resistance.

Since it is important to maintain the antibacterial activity of fabrics in conditions of use, the antibacterial activity of unwashed fabrics was also compared with washed fabrics.

\section{MATERIAL AND METHOD}

\subsection{Material}

$100 \%$ cotton fabric was used for this study which was selected due to its wide usage in surgical textile protective clothing. The substrates were characterised with respect to their weight and thickness, the data of which is shown in Table 1.

The cotton fabric had a twill weave, with a weight of $336,79 \mathrm{~g} / \mathrm{m}^{2}$, and a thickness of $0,4545 \mathrm{~mm}$.

\section{Metal oxides}

Basis and below $5 \mu \mathrm{m}$ copper(I)oxide particles, below $10 \mu \mathrm{m}$ copper(II)oxide particles and below $5 \mu \mathrm{m}$ zinc oxide particles (Sigma Aldrich) pattern were used as supplied.

\section{Cross-linkings}

At high temperatures, carboxylic acids form ester-type crosslinking with cellulose molecules and provide antibacterial activity. For this purpose, BTCA and CA were used in this study. Since these two carboxylic acids make effective cross-linking in the combined use of phosphoruscontaining acids with inorganic salts, sodiumhypophosphite was added as a catalyst in pre-treatment bath.

BTCA was obtained in powder form from Fluka and CA was obtained from Sigma-Aldrich. The both chemicals were used as supplied. The composition of pre-treatment baths including BTCA and SHP, and CA and SHP were presented in Table 1. Cupper oxide and zinc oxide were assimilated in the coating bath for the antibacterial property. Coating bath formulation containing $90 \%$ of the arcylate binder is given in the Table 2 .

Table 1. Composition of pre-treatment baths ${ }^{49}$

\begin{tabular}{|l|c|c|c|c|}
\hline Treatments & BTCA, g & CA, g & SHP, g & Pure water, $\mathrm{ml}$ \\
\hline $\begin{array}{l}2,5 \% \text { BTCA+1\% } \\
\text { SHP }\end{array}$ & 30 & - & 12 & 1000 \\
\hline $\begin{array}{l}2,5 \% \\
\text { CA+1\%SHP }\end{array}$ & - & 30 & 12 & 1000 \\
\hline
\end{tabular}

Table 2. Coating bath formulation containing $90 \%$ of the arcylate binder ${ }^{49}$

\begin{tabular}{|l|l|}
\hline Polyacrylate binder 1 & $45 \%$ \\
\hline Polyarcylate binder 2 & $45 \%$ \\
\hline $\mathrm{BTCA} / \mathrm{CA}$ & $5 \%$ \\
\hline $\mathrm{Cu}_{2} \mathrm{O}, \mathrm{CuO}$ and $\mathrm{ZnO}$ & $1 \%$ \\
\hline Emulsified, dispersing material & $3 \%$ \\
\hline Thickener & $1 \%$ \\
\hline Coating thickness & $0,1 \mathrm{~mm}$ \\
\hline Drying & $100^{\circ} \mathrm{C} / 2 \mathrm{~min}$ \\
\hline Curing & $150^{\circ} \mathrm{C} / 2 \mathrm{~min}$ \\
\hline
\end{tabular}

\subsection{Determination of antibacterial effects of treated fabrics}

In this study as gram-positive bacteria (Staphylococcus aureus (ATCC 43300) and Bacillus subtilis (NRRL NRS- 
744)) and as gram-negative bacteria (Esherichia coli (ATCC 35218) and Klebsiella pneumoniae (ATCC 70063)) were used. The culture medium Nutrient Agar (NA) used for the cultivation of the bacterial strains deployed in this work, were prepared according to the instructions of the manufacturer.

Antibacterial activity of cotton fabrics were tested against bacterial strains before washing and after 20 wash cycles according to the JIS L 1902-Halo Method (2008) protocol. The culture medium Nutrient Broth (NB) and Nutrient Agar (NA) were used for the cultivation of the bacterial strains. Culture media were dissolved directly after being weighed in deionized distilled water, and then sterilized by autoclaving for $15 \mathrm{~min}$ at $121{ }^{\circ} \mathrm{C} 48$.

The protocol from JIS L 1902-Halo Method was performed as follows: The bacteria was incubated for $24 \mathrm{~h}$ at $37^{\circ} \mathrm{C}$ in nutrient broth (NB). Then, $1.0 \pm 0.1 \mathrm{ml}$ from the inoculum with $1 \times 10^{7} \mathrm{CFU} / \mathrm{ml}$ was added to $15 \mathrm{ml}$ of NA warmed at $45-46^{\circ} \mathrm{C}$. After agar solidification, the cotton fabrics (size $25 \times 25 \mathrm{~mm}$ ) were placed on the agar surface and incubated at a temperature of $37^{\circ} \mathrm{C}$ for 24 hours. Then, the diameter of the fabrics were measured by measuring the diameter around the fabric (inhibition zone diameter) ${ }^{48}$.

\subsection{Metal oxide applications}

Cotton fabric were double padded in the dispersion of micro copper(I)oxide $\left(\mathrm{Cu}_{2} \mathrm{O}\right)$, cupper(II)oxide $(\mathrm{CuO})$ and zinc oxide $(\mathrm{ZnO})$ particles (with concentration of $1 \mathrm{~g} / \mathrm{dm}^{3}$ ) in the nano-styrene acrylate copolymer binders finishing bath using a laboratory padding and $0,1 \mathrm{~mm}$ coating thickness. Then the cotton samples were dried at $100{ }^{\circ} \mathrm{C}$ for $2 \mathrm{~min}$ and cured at $150^{\circ} \mathrm{C}$ for $2 \mathrm{~min}{ }^{49}$.

\subsection{Measurements}

Infrared spectra of the samples were recorded in reflection mode using a Fourier-Transform Perkin Elmer 2000 FT-IR spectrometer. An attenuated total unit was fitted with a $45^{\circ}$ entrance angle. Thirty scans were taken for each sample.

A field emission scanning electron microscope was used to observe the samples spattered with a $82.9 \mu \mathrm{m}$ thick layer.

\section{RESULTS AND DISCUSSION}

\subsection{Morphology of treated cotton fabric samples through SEM}

The distribution of basis and micro copper (I) oxide particles on the structure of the fabric after nano-styrene acrylate copolymer coatings were investigated by SEM analysis ${ }^{49}$.

All samples were washed in distilled water to remove soluble and superficially attached reagents. The images showed an obvious change in the surface morphology of the treated samples with respect to the untreated cotton fabric.

The untreated cotton fabric as observed by SEM showed typical longitudinal fibrils on the surface ${ }^{49}$.

The SEM images of the uncoated and basis and microcopper oxide applied fabrics particles were given in Figure
1. When SEM images were considered, the presence of basis and micro particles on fabric structure was clearly observed. It could be seen from the SEM images that micro-sized copper oxide particles penetrated to the fiber surface and showed a homogenous distribution. It was observed that hard and soft acrylic binders used in the coating application were polymerized and they were hold on the surface ${ }^{49}$.

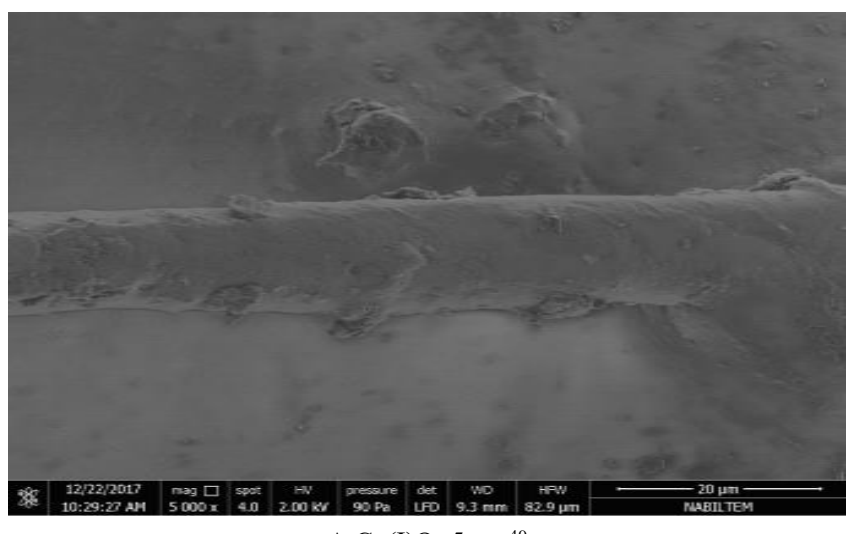

$\mathrm{A}: \mathrm{Cu}(\mathrm{I}) \mathrm{O}<5 \mu \mathrm{m}^{49}$

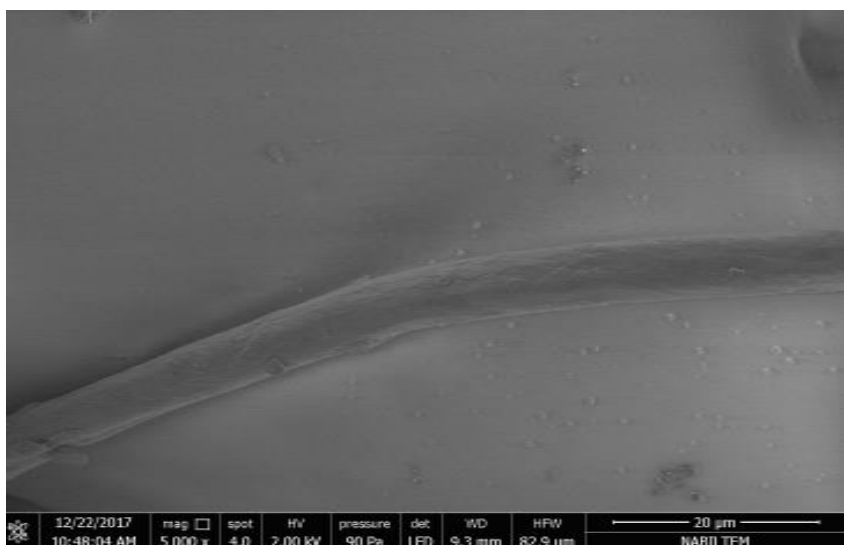

$\mathrm{B}: \mathrm{Cu}(\mathrm{II}) \mathrm{O}<10 \mu \mathrm{m}^{49}$

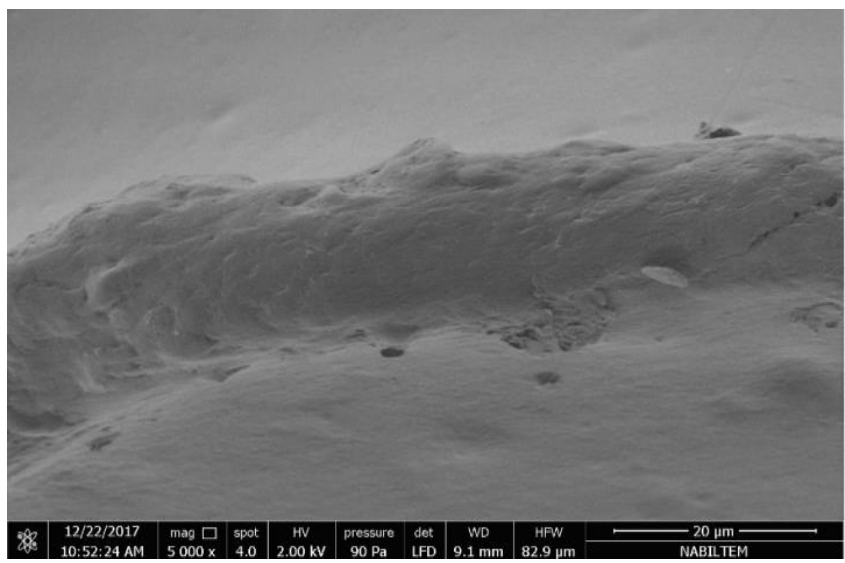

$\mathrm{C}: \mathrm{ZnO}<5 \mu \mathrm{m}^{49}$

Figure 1. Cotton fiber surfaces before and after antibacterial coating processes $(\mathrm{A}$ : $\mathrm{Cu}(\mathrm{I}) \mathrm{O}<5 \mu \mathrm{m}, \mathrm{B}: \mathrm{Cu}(\mathrm{II}) \mathrm{O}<10$ $\mu \mathrm{m}, \mathrm{C}: \mathrm{ZnO}<5 \mu \mathrm{m}{ }^{49}$

\subsection{FTIR spectra after applications}

The FTIR spectra of pretreated and then antibacterial coated cotton fabric samples were shown in Figures 2, 3, 4, 5 and 6 . 
Figure 2 showed the FTIR spectra of cotton fabric pretreated BTCA and SHP and then treatment with arylic coating polycarboxylic acids, the bands $\mathrm{OH}$ and $\mathrm{CH}(2900$ and $\left.2161 \mathrm{~cm}^{-1}\right), \mathrm{OH}$ and $\mathrm{CH}$ bending (1646,1428 and 1315 $\left.\mathrm{cm}^{-1}\right) \mathrm{CC}$ and CO tensile $\left(1160,1108\right.$ and $\left.1030 \mathrm{~cm}^{-1}\right)$ bands were obtained dense band at $1646 \mathrm{~cm}^{-1}$ is the $\mathrm{C}=0$ stresses from the hydrogen bonded carboxylic acid and the change in the transmittance band at $1646 \mathrm{~cm}^{-1}$ is due to the deformation vibration of the hydroxyl groups.

The two bands in 1315 and $1030 \mathrm{~cm}^{-1}$ are due to the deformation of the hydrogen-linked carboxylic acid in the plane sequence and the $\mathrm{C}-\mathrm{O} \operatorname{strain}^{47}$. As a result, the change in the bands $3000-2800 \mathrm{~cm}^{-1}$ and $1200-800 \mathrm{~cm}^{-1}$ indicated that the number of $\mathrm{OH}$ groups increased after the procedure.

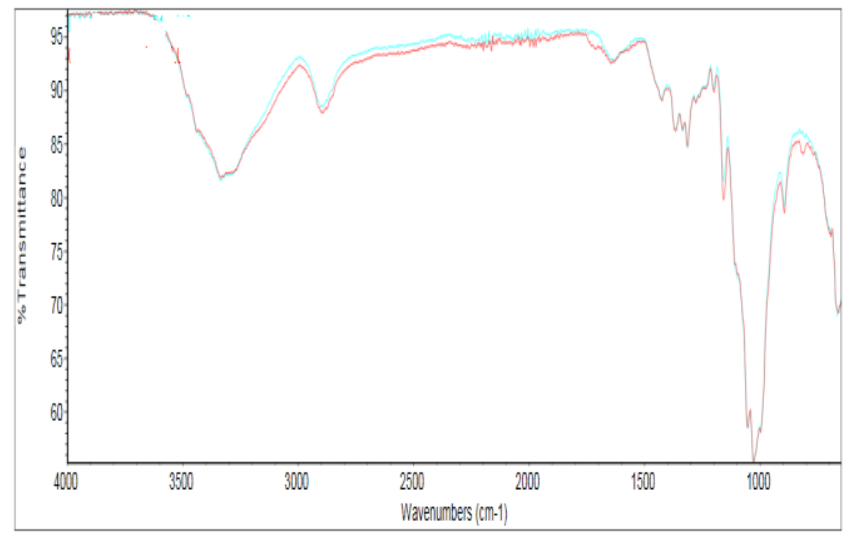

Figure 2. FTIR-ATR spectra of cotton fabric treated with $\mathrm{Cu}(\mathrm{I}) \mathrm{O}$ basis antibacterial particle and arylic coating antibacterial after application of BTCA ${ }^{49}$

Figure 3 showed the FTIR spectra of cotton fabric pretreated CA and SHP and then treatment with arylic coating polycarboxylic acids with $\mathrm{Cu}(\mathrm{I}) \mathrm{O}$ basis antibacterial particle. The bands formed after the process showed similarity with Figure 2. The change in the bands $3000-2800 \mathrm{~cm}^{-1}$ indicated that the number of $\mathrm{OH}$ groups increased after the CA polycarboxylic acid. In summary, the change in the FTIR-ATR spectrum of cotton fabric treated with $\mathrm{CA}$ followed by $\mathrm{Cu}$ (I) $\mathrm{O}$ basis antibacterial particle via acrylic coating appears to be greater than the one treated with BTCA.

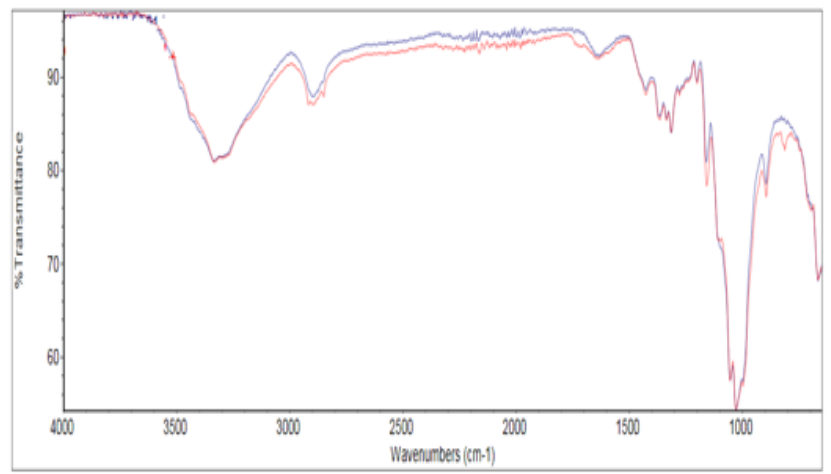

Figure 3. FTIR-ATR spectra of cotton fabric treated with $\mathrm{Cu}(\mathrm{I}) \mathrm{O}$ basis antibacterial particle via acrylic coating after application of citric acid monohydrate ${ }^{49}$
Figure 4 showed the FTIR spectra of cotton fabric pretreated BTCA and SHP and treatment with arylic coating polycarboxylic acids with $\mathrm{Cu}(\mathrm{I}) \mathrm{O}<5 \mu \mathrm{m}$ antibacterial particle.

The spectra obtained from pretreated and then antibacterial coated cotton fabric samples are very similar, but the spectra for BTCA and SHP pre-treated cotton showed some difference in the peaks of two strong bands at $2161 \mathrm{~cm}^{-1}$, $1730 \mathrm{~cm}^{-1}$ and $1570 \mathrm{~cm}^{-1}$ which are due to the ester and carboxylate carbonyls, respectively ${ }^{50-52}$.

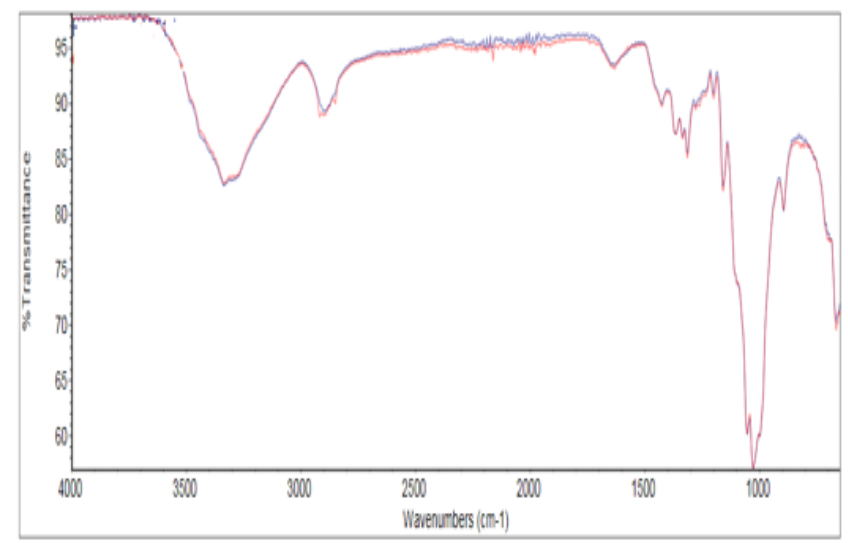

Figure 4. FTIR-ATR spectra of cotton fabric treated with $\mathrm{Cu}$ (I) $\mathrm{O}<5 \mu \mathrm{m}$ antibacterial after application of $\mathrm{BTCA}^{49}$

Figure 5 showed FTIR-ATR spectra of cotton fabric pretreated with citric acid monohydrate and then treated arylic coating polycarboxylic acids with $\mathrm{Cu}(\mathrm{I}) \mathrm{O}<5 \mu \mathrm{m}$ antibacterial particle. The bands formed after the process were similar to the ones presented in Figure 4.The two bands in 1315 and $1030 \mathrm{~cm}^{-1}$ were due to the $\mathrm{OH}$ deformation and $\mathrm{C}-\mathrm{O}$ stretching of the hydrogen bonded carboxylic acid outside the plane. O-H bands at $1645 \mathrm{~cm}^{-1}$ were completely closed.

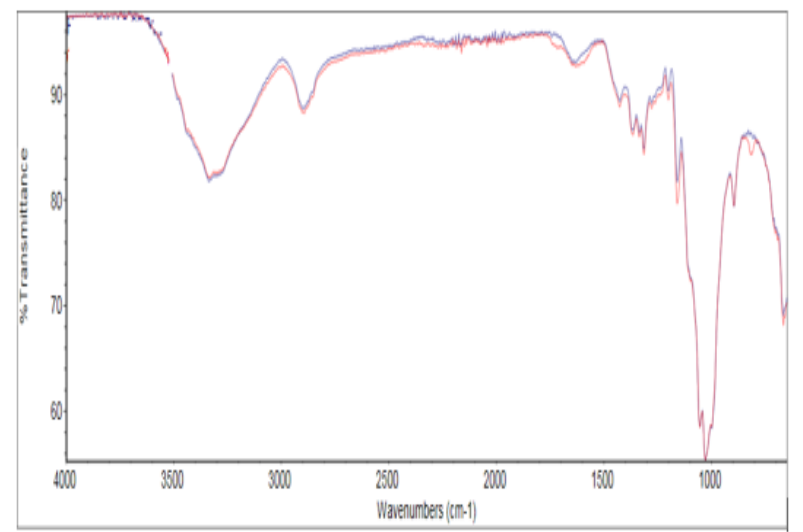

Figure 5. FTIR-ATR spectra of cotton fabric treated with $\mathrm{Cu}(\mathrm{I}) \mathrm{O}<5 \mu \mathrm{m}$ antibacterial particle via acrylic coating after the application of citric acid monohydrate ${ }^{49}$

Figure 6 showed FTIR-ATR spectra of cotton fabric treated with citric acid monohydrate and then treated with $\mathrm{ZnO}<5 \mu \mathrm{m}$ antibacterial particle via acrylic coating. As a result, the change in the bands of $3000-2800 \mathrm{~cm}^{-1}$ and 1200 $800 \mathrm{~cm}^{-1}$ indicated that the number of $\mathrm{OH}$ groups increased after the procedure. The change in the band of $2161 \mathrm{~cm}^{-1}$ 
and $1646 \mathrm{~cm}^{-1}$ showed that the citric acid monohydrate, which is a polycarboxylic acid, was bound to free hydroxyl groups of cotton.

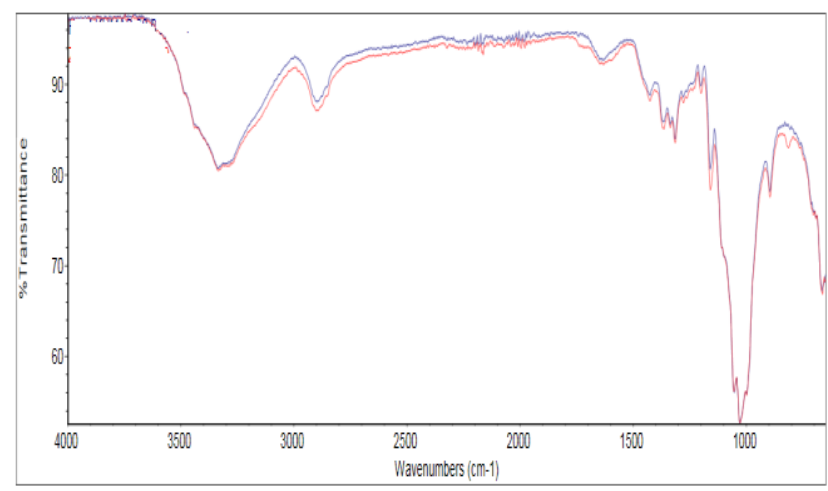

Figure 6. FTIR-ATR spectra of cotton fabric treated with $\mathrm{ZnO}<5 \mu \mathrm{m}$ antibacterial particle via acrylic coating after the application of citric acid monohydrate ${ }^{49}$

\subsection{Comparision of antibacterial effects of treated fabrics according to wash cycles}

To evaluate the antimicrobial efficiency according to protocol of the treated fabrics JIS L 1902-Halo Method (2008), the inhibition zones of the attempted fabrics formed on selected microorganisms were assessed.

In order to determine the resistance of the antibacterial treatments to washing the fabric samples were washed with twenty times. However, after the seventeenth wash no zone formation was observed. The treated fabrics were laundered in an Atlas Launder-Ometer according to AATCC Test Method 61, Test 1A. The test is intended to simulate five home launderings. The antibacterial efficiency of the laundered fabrics were evaluated again after the wash tests. Results of these experiments are presented in Tables 2,3, 4,5 .

Table 2. Inhibition zones of treated fabrics after wash cycles against S. aureus (ATCC 43300) ${ }^{49}$

\begin{tabular}{|c|c|c|c|c|c|c|c|c|c|c|}
\hline \multirow[t]{2}{*}{ Fabricno } & \multicolumn{10}{|c|}{ Inhibition zone (mm) } \\
\hline & - & $1^{n}$ & $3^{\text {ra }}$ & $5^{m}$ & $7^{2}$ & $10^{2}$ & $13^{k}$ & $15^{m}$ & $17^{2}$ & $20^{4}$ \\
\hline $\begin{array}{l}\mathrm{Cu}(\mathrm{I}) 0<5 \mu \mathrm{m} \\
+\mathrm{BCA}\end{array}$ & 32 & 31 & 27 & 27 & 27 & 27 & 27 & 26 & 26 & 0 \\
\hline $\begin{array}{l}\mathrm{Cu}(\mathrm{I}) 0<5 \mu \mathrm{m} \\
+\mathrm{CA}\end{array}$ & 27 & 26 & 0 & 0 & 0 & 0 & 0 & 0 & 0 & 0 \\
\hline $\begin{array}{l}\mathrm{Cu}(\mathrm{I}) \mathrm{O} \\
\text { basis+CA }\end{array}$ & 33 & 32 & 30 & 30 & 0 & 0 & 0 & 0 & 0 & 0 \\
\hline $\begin{array}{l}\mathrm{Cu}(\mathrm{I}) \mathrm{O} \\
\text { basis+BTCA }\end{array}$ & 30 & 29 & 26 & 0 & 0 & 0 & 0 & 0 & 0 & 0 \\
\hline $\begin{array}{l}\text { Cu(II) } 0<10 \mu \mathrm{m} \\
+ \text { +BTCA }\end{array}$ & 32 & 0 & 0 & 0 & 0 & 0 & 0 & 0 & 0 & 0 \\
\hline $\begin{array}{l}\mathrm{Cu}(\mathrm{II}) 0 \leqslant 10 \mu \mathrm{m} \\
+\mathrm{CA}\end{array}$ & 29 & 0 & 0 & 0 & 0 & 0 & 0 & 0 & 0 & 0 \\
\hline $\begin{array}{l}\mathrm{ZnO<5 \mu \textrm {m } +} \\
\text { BTCA }\end{array}$ & 27 & 27 & 0 & 0 & 0 & 0 & 0 & 0 & 0 & 0 \\
\hline $\begin{array}{l}\mathrm{Zno}<5 \mu \mathrm{m}+ \\
\mathrm{CA}\end{array}$ & 32 & 32 & 27 & 0 & 0 & 0 & 0 & 0 & 0 & 0 \\
\hline
\end{tabular}

The antimicrobial efficiency of the unwashed fabrics; $\mathrm{ZnO}+\mathrm{CA}$ treated fabric had showed the best antibacterial activity for $B$. subtilis $(37 \mathrm{~mm})$ and $\mathrm{Cu}(\mathrm{I}) \mathrm{O}<5 \mu \mathrm{m}+\mathrm{BTCA}$ treated fabric had good effect against E. coli $(36 \mathrm{~mm})$ (Table 2) (Figure 7,8,9,10).
Table 3. Inhibition zones of treated fabrics after wash cycles against B. subtilis (NRRL NRS-744) ${ }^{49}$

\begin{tabular}{|c|c|c|c|c|c|c|c|c|c|c|}
\hline \multirow[t]{2}{*}{ Fabricno } & \multirow{2}{*}{\multicolumn{10}{|c|}{ Inhibition zone (mm) }} \\
\hline & & & $3^{\text {ra }}$ & & & & $13^{\mathrm{a}}$ & $15^{3}$ & $17^{a}$ & \\
\hline $\begin{array}{l}\mathrm{Cu}(\mathrm{I}) \mathrm{O}<5 \mu \mathrm{m} \\
+\mathrm{BCA}\end{array}$ & 35 & 32 & 30 & 29 & 26 & 26 & 26 & 0 & 0 & 0 \\
\hline $\begin{array}{l}\mathrm{Cu}(\mathrm{I}) \mathrm{O}<5 \mu \mathrm{m} \\
+\mathrm{CA}\end{array}$ & 26 & 26 & 26 & 26 & 0 & 0 & 0 & 0 & 0 & 0 \\
\hline $\begin{array}{l}\mathrm{Cu}(\mathrm{I}) \mathrm{O} \\
\text { basis +CA }\end{array}$ & 36 & 30 & 28 & 28 & 28 & 28 & 0 & 0 & 0 & 0 \\
\hline $\begin{array}{l}\text { Cu(I)O } \\
\text { basis+BTCA }\end{array}$ & 29 & 28 & 26 & 26 & 0 & 0 & 0 & 0 & 0 & 0 \\
\hline $\begin{array}{l}\text { Cu(II)O }<10 \mu \mathrm{m} \\
+ \text { +BTCA }\end{array}$ & 33 & 30 & 0 & 0 & 0 & 0 & 0 & 0 & 0 & 0 \\
\hline $\begin{array}{l}\mathrm{Cu}(\mathrm{II}) \mathrm{O} \approx 10 \mu \mathrm{m} \\
+\mathrm{CA}\end{array}$ & 33 & 0 & 0 & 0 & 0 & 0 & 0 & 0 & 0 & 0 \\
\hline $\begin{array}{l}\mathrm{ZnO}<5 \mu \mathrm{m}+ \\
\mathrm{BTCA}\end{array}$ & 27 & 27 & 27 & 27 & 0 & 0 & 0 & 0 & 0 & 0 \\
\hline $\mathrm{Zno}_{\mathrm{CA}}=5 \mu \mathrm{m}+$ & 37 & 34 & 26 & 26 & 0 & 0 & 0 & 0 & 0 & 0 \\
\hline
\end{tabular}

Table 4. Inhibition zones of treated fabrics after wash cycles against E. coli (ATCC 35218) ${ }^{49}$

\begin{tabular}{|c|c|c|c|c|c|c|c|c|c|c|}
\hline \multirow[t]{2}{*}{ Fabricno } & \multicolumn{10}{|c|}{ Inhibition zone (mm) } \\
\hline & - & $1^{n}$ & $3^{\text {ra }}$ & $5^{*}$ & $7^{*}$ & $10^{\mathrm{e}}$ & $13^{\mathrm{m}}$ & $15^{\mathrm{k}}$ & $17^{4}$ & $20^{\mathrm{m}}$ \\
\hline $\begin{array}{l}\mathrm{Cu}(\mathrm{I}) 0<5 \mu \mathrm{m} \\
+\mathrm{BCA}\end{array}$ & 36 & 31 & 31 & 31 & 28 & 0 & 0 & 0 & 0 & 0 \\
\hline $\begin{array}{l}\mathrm{Cu}(\mathrm{I}) 0<5 \mu \mathrm{m} \\
+\mathrm{CA}\end{array}$ & 27 & 27 & 0 & 0 & 0 & 0 & 0 & 0 & 0 & 0 \\
\hline $\begin{array}{l}\mathrm{Cu}(\mathrm{I}) 0 \\
\text { basis }+\mathrm{CA}\end{array}$ & 33 & 30 & 28 & 27 & 0 & 0 & 0 & 0 & 0 & 0 \\
\hline $\begin{array}{l}\text { Cu(I)O } \\
\text { basis+BTCA }\end{array}$ & 30 & 29 & 0 & 0 & 0 & 0 & 0 & 0 & 0 & 0 \\
\hline $\begin{array}{l}\mathrm{Cu}(\mathrm{II}) 0<10 \mu \mathrm{m} \\
+\mathrm{BTCA}\end{array}$ & 0 & 0 & 0 & 0 & 0 & 0 & 0 & 0 & 0 & 0 \\
\hline $\begin{array}{l}\mathrm{Cu}(\mathrm{II}) 0 \leqslant 10 \mu \mathrm{m} \\
+\mathrm{CA}\end{array}$ & 29 & 0 & 0 & 0 & 0 & 0 & 0 & 0 & 0 & 0 \\
\hline $\begin{array}{l}\mathrm{ZnO}=5 \mu \mathrm{m}+ \\
\mathrm{BTCA}\end{array}$ & 28 & 0 & 0 & 0 & 0 & 0 & 0 & 0 & 0 & 0 \\
\hline $\begin{array}{l}\mathrm{Zno}<5 \mu \mathrm{m}+ \\
\mathrm{CA}\end{array}$ & 31 & 29 & 0 & 0 & 0 & 0 & 0 & 0 & 0 & 0 \\
\hline
\end{tabular}

Table 5. Inhibition zones of treated fabrics after wash cycles against K. pneumoniae (ATCC 70063) ${ }^{49}$

\begin{tabular}{|c|c|c|c|c|c|c|c|c|c|c|}
\hline \multirow[t]{2}{*}{ Fabricno } & \multicolumn{10}{|c|}{ Inhibition zone $(\mathrm{mm})$} \\
\hline & - & $1^{\text {tt }}$ & $3^{\text {ra }}$ & $5^{\mathrm{m}}$ & $7^{ \pm}$ & $10^{*}$ & $13^{2}$ & $15^{*}$ & $17^{m}$ & $20^{\mathrm{m}}$ \\
\hline $\begin{array}{l}\mathrm{Cu}(\mathrm{I}) \mathrm{O}<5 \mu \mathrm{m} \\
+\mathrm{BCA}\end{array}$ & 32 & 31 & 31 & 27 & 0 & 0 & 0 & 0 & 0 & 0 \\
\hline $\begin{array}{l}\mathrm{Cu}(\mathrm{I}) 0<5 \mu \mathrm{m} \\
+\mathrm{CA}\end{array}$ & 31 & 27 & 26 & 26 & 0 & $\begin{array}{llll}0 & & & \\
\end{array}$ & 0 & 0 & 0 & 0 \\
\hline $\begin{array}{l}\mathrm{Cu}(\mathrm{I}) \mathrm{O} \\
\text { basis +CA }\end{array}$ & 32 & 30 & 26 & 26 & 0 & 0 & 0 & 0 & 0 & 0 \\
\hline $\begin{array}{l}\mathrm{Cu}(\mathrm{I}) \mathrm{O} \\
\text { basis+BTCA }\end{array}$ & 0 & 0 & 0 & 0 & 0 & 0 & 0 & 0 & 0 & 0 \\
\hline $\begin{array}{l}\text { Cu(II)O } \approx 10 \mu \mathrm{m} \\
+\mathrm{BTCA}\end{array}$ & 0 & 0 & 0 & 0 & 0 & 0 & 0 & 0 & 0 & 0 \\
\hline $\begin{array}{l}\mathrm{Cu}(\mathrm{III}) 0 \approx 10 \mu \mathrm{m} \\
+\mathrm{CA}\end{array}$ & 28 & 0 & 0 & 0 & 0 & 0 & 0 & 0 & 0 & 0 \\
\hline $\begin{array}{l}\mathrm{ZnO} O=5 \mu \mathrm{m}+ \\
\text { BTCA }\end{array}$ & 0 & 0 & 0 & 0 & 0 & 0 & 0 & 0 & 0 & 0 \\
\hline $\begin{array}{l}\mathrm{Zno}<5 \mu \mathrm{m}+ \\
\mathrm{CA}\end{array}$ & 32 & 31 & 30 & 0 & 0 & 0 & 0 & 0 & 0 & 0 \\
\hline
\end{tabular}

1 g. $\mathrm{Cu}$ (I) O basis + BTCA as well as $1 \mathrm{~g}$. $\mathrm{ZnO}+\mathrm{BTCA}$ were the largest samples in the area of the fabric samples containing acrylic coating. As it could be seen from Table 4, 5 inhibition zones were not detected on the $\mathrm{Cu}(\mathrm{I}) \mathrm{O}$ basis $+\mathrm{BTCA}, \mathrm{Cu}(\mathrm{II}) \mathrm{O}<10 \mu \mathrm{m}+\mathrm{BTCA}$ and $\mathrm{ZnO}+\mathrm{BTCA}$ againts $E$. coli or $K$. pneumoniae.

Antibacterial activity of washed treated fabrics against Gram positive bacteria ( $S$. aureus and B. subtilis) and was greater than that against Gram negative bacteria (E. coli and $K$. pneumoniae). Samples with the highest inhibition zone against bacteria were $30 \mathrm{~g} / \mathrm{L}$ BTCA, $12 \mathrm{~g} / \mathrm{L}$ sodium hypophosphite pretreatment applied by $\mathrm{Cu}(\mathrm{I}) \mathrm{O}<5 \mu \mathrm{m}+$ BTCA. When the washing stability of these different bacteria was compared, it was determined that $\mathrm{Cu}(\mathrm{I}) \mathrm{O}<5 \mu \mathrm{m}+\mathrm{BTCA}$ had good antibacterial effects even after 17 washes against $S$. aureus and 13 washes against $B$. subtilis and 7 washes against $E$. coli. But after 20 washes, it did not show antibacterial effect for S.aureus (Table 2). Likewise, $\mathrm{Cu}(\mathrm{I}) \mathrm{O}$ basis+CA had good antibacterial effects even after 10 washes against B. subtilis (Figure 11,12,13). 
Some treated fabrics had lost antimicrobial activity in their first washings. Especially, $\mathrm{Cu}(\mathrm{II}) \mathrm{O}<10 \mu \mathrm{m}+\mathrm{CA}$ fabric did not show antimicrobial effect after the first wash against all microorganism. Likewise, with washing of $\mathrm{Cu}(\mathrm{II}) \mathrm{O}<50 \mathrm{~nm}+$ $\mathrm{CA}$ and $\mathrm{Cu}(\mathrm{II}) \mathrm{O}<10 \mu \mathrm{m}+\mathrm{BTCA}$ fabrics, no inhibition zone was observed against $\mathrm{S}$. aureus and in $\mathrm{ZnO}+\mathrm{BTCA}$ fabric against E.coli.

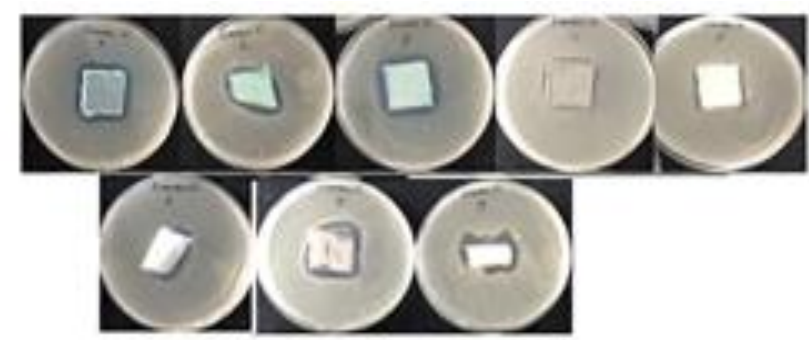

Figure 7. Inhibition zones of treated fabrics before washing against $\mathrm{S}$. aureus $(1: \mathrm{Cu}(\mathrm{I}) \mathrm{O}<5 \mu \mathrm{m}+\mathrm{BTCA}, 2: \mathrm{Cu}(\mathrm{I}) \mathrm{O}$ basis+BTCA, 3: $\mathrm{Cu}(\mathrm{I}) \mathrm{O}$ basis $+\mathrm{CA}, 4: \mathrm{Cu}(\mathrm{II}) \mathrm{O}<10 \mu \mathrm{m}+$ CA, $5: \mathrm{ZnO}<5 \mu \mathrm{m}+\mathrm{BTCA}, 6: \mathrm{Cu}(\mathrm{I}) \mathrm{O}<5 \mu \mathrm{m}+\mathrm{CA}, 7: \mathrm{Cu}(\mathrm{II})$ $\mathrm{O}<10 \mu \mathrm{m}+\mathrm{BTCA}, 8: \mathrm{ZnO}<5 \mu \mathrm{m}+\mathrm{CA})^{49}$

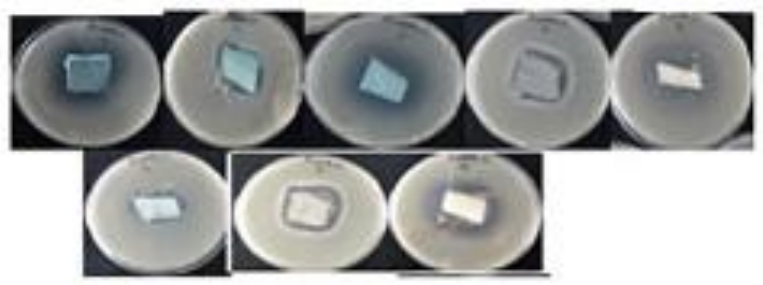

Figure 8. Inhibition zones of treated fabrics before washing against $B$. subtilis $(1: \mathrm{Cu}(\mathrm{I}) \mathrm{O}<5 \mu \mathrm{m}+\mathrm{BTCA}, 2: \mathrm{Cu}(\mathrm{I}) \mathrm{O}$ basis+BTCA, 3:Cu(I)O basis+CA， 4:Cu(II)O $<10 \mu \mathrm{m}+$ CA, $5: \mathrm{ZnO}<5 \mu \mathrm{m}+\mathrm{BTCA}, 6: \mathrm{Cu}(\mathrm{I}) \mathrm{O}<5 \mu \mathrm{m}+\mathrm{CA}, 7: \mathrm{Cu}(\mathrm{II})$ $\mathrm{O}<10 \mu \mathrm{m}+\mathrm{BTCA}, 8: \mathrm{ZnO}<5 \mu \mathrm{m}+\mathrm{CA})^{49}$

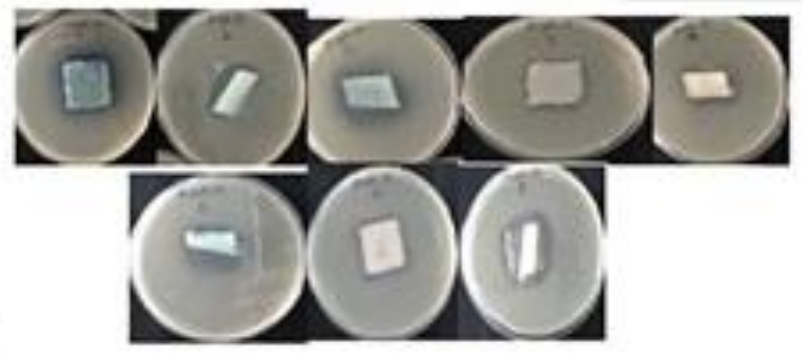

Figure 9. Inhibition zones of treated fabrics before washing against E. coli $(1: \mathrm{Cu}(\mathrm{I}) \mathrm{O}<5 \mu \mathrm{m}+\mathrm{BTCA}, \quad 2: \mathrm{Cu}(\mathrm{I}) \mathrm{O}$ basis + BTCA, 3: $\mathrm{Cu}(\mathrm{I}) \mathrm{O}$ basis $+\mathrm{CA}, \quad 4: \mathrm{Cu}(\mathrm{II}) \mathrm{O}<10 \mu \mathrm{m}+$ $\mathrm{CA}, \quad 5: \mathrm{ZnO}<5 \mu \mathrm{m}+\quad \mathrm{BTCA}, \quad 6: \mathrm{Cu}(\mathrm{I}) \mathrm{O}<5 \mu \mathrm{m}+\mathrm{CA} 7:$ $\mathrm{Cu}(\mathrm{II}) \mathrm{O}<10 \mu \mathrm{m}+\mathrm{BTCA}, 8: \mathrm{ZnO}<5 \mu \mathrm{m}+\mathrm{CA})^{49}$

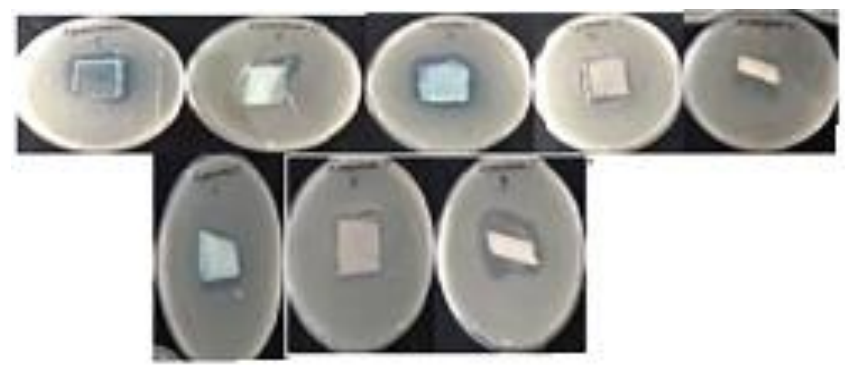

Figure 10. Inhibition zones of treated fabrics before washing against K. pneumonia $(1: \mathrm{Cu}(\mathrm{I}) \mathrm{O}<5 \mu \mathrm{m}+\mathrm{BTCA}$, 2: $\mathrm{Cu}(\mathrm{I}) \mathrm{O}$ basis+BTCA, 3:Cu(I)O basis+CA, 4:Cu(II) $\mathrm{O}<10 \mu \mathrm{m}+\mathrm{CA}, 5: \mathrm{ZnO}<5 \mu \mathrm{m}+\mathrm{BTCA}, 6: \mathrm{Cu}(\mathrm{I}) \mathrm{O}<5 \mu \mathrm{m}+$ CA, 7:Cu(II)O $<10 \mu \mathrm{m}+\mathrm{BTCA}, 9: \mathrm{ZnO}<5 \mu \mathrm{m}+\mathrm{CA})^{49}$

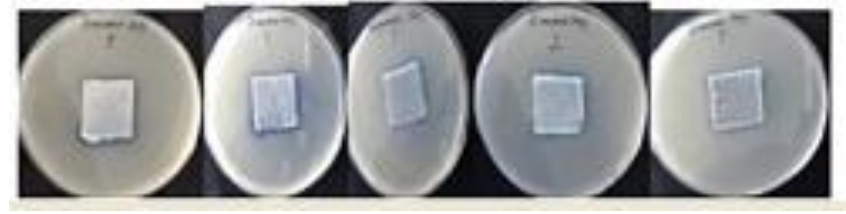

Figure 11. Inhibition zones of $\mathrm{Cu}(\mathrm{I}) \mathrm{O}<5 \mu \mathrm{m}+\mathrm{BTCA}$ fabrics after $1,5,10,15,17$ wash cycles against $S$. Aureus ${ }^{49}$

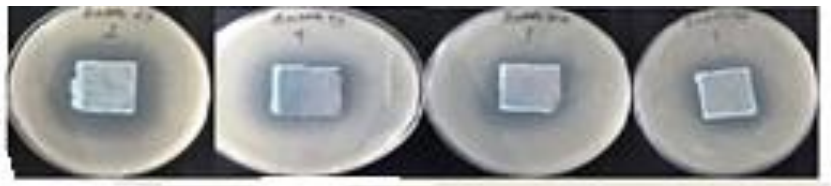

Figure 12. Inhibition zones of $\mathrm{Cu}(\mathrm{I}) \mathrm{O}<5 \mu \mathrm{m}+\mathrm{BTCA}$ fabrics after $1,5,10,15,13$ wash cycles against B. Subtilis ${ }^{49}$

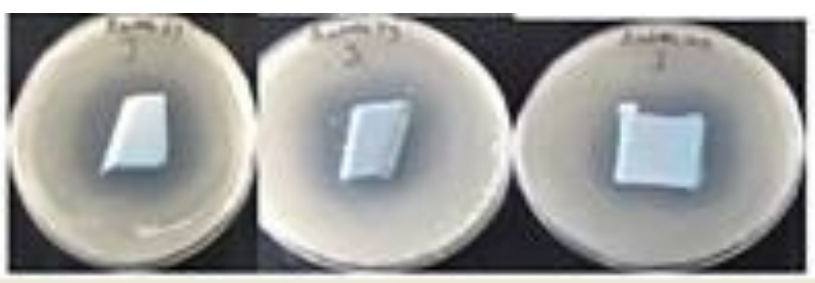

Figure 13. Inhibition zones of $\mathrm{Cu}(\mathrm{I}) \mathrm{O}$ basis+CA fabrics after $1,5,10$ wash cycles against B. Subtilis ${ }^{49}$

\section{CONCLUSIONS}

The results of the usage of some metal oxides on the antibacterial and washing resistance properties of cotton fabrics were investigated. The relationship between the structural and morphological properties of $\mathrm{CuO}, \mathrm{Cu} 2 \mathrm{O}$ and $\mathrm{ZnO}$-coated fabrics was presented. The uniform coating of the cotton fabrics with $\mathrm{CuO}, \mathrm{Cu} 2 \mathrm{O}$ and $\mathrm{ZnO}$ microparticles were confirmed by FTIR and SEM. The inhibition zones of treated fabrics after multiple wash cycles were studied. The antibacterial activities of the optimized sample were tested using some species of gram-positive and gram-negative bacteria.

Experimental results showed that the most inhibited species were B.subtilis and S.aureus. It is well known that microparticles of some metal-oxides such as copper $(\mathrm{Cu} 2 \mathrm{O})$ and zinc $(\mathrm{ZnO})$ belong to a group of compounds with antibacterial properties. In this research, the samples with the highest inhibition zone were observed with $30 \mathrm{~g} / \mathrm{L}$ BTCA and $12 \mathrm{~g} / \mathrm{L}$ sodium hypophosphite pretreatment which were applied by $\mathrm{Cu}(\mathrm{I}) \mathrm{O}<5 \mu \mathrm{m}+\mathrm{BTCA}$ nano-styrene arcylate copolymer coating treated fabric. When the stability and antibacterial efficiency of this treated fabric on different bacteria against washing were compared, it was determined that $\mathrm{Cu}(\mathrm{I}) \mathrm{O}<5 \mu \mathrm{m}+\mathrm{BTCA}$ had good antibacterial resistance even after 17 washes against $\mathrm{S}$. aureus, after 13 washes against B. subtilis and after 7 washes against E. coli.

\section{Acknowledgements}

This work was supported by the Namık Kemal University Scientific Research Projects Commission (NKUBAP. 06.GA.16.064) 


\section{Declaration}

The author(s) declared no potential conflicts of interest with respect to the research, authorship, and/or publication of

\section{REFERENCES}

1. Swicofil, http://www.swicofil.com/products/016nettle.html. Accessed on 2014.

2. Kurban M. Pre-treatment of Nettle Fibre Fabrics. MSc Thesis, Pamukkale University, Turkey, 2012.

3. Schindler WD and Hauser PJ. Chemical Finishing of Textiles. Cambridge: Woodhead Publishing, 2004.

4. Lam YL, Kan CW and Yuen CWM. Wrinkle-resistant Finishing of Cotton Fabric with BTCA-The Effect of Co-catalyst. Textile Research Journal 2010; 81(5): 482-493.

5. Harifi T and Montazer M. Past, Present and Future Prospects of Cotton Cross-linking: New insight into nanoparticles. Carbohydrate Polymers 2012; 88: 1125-1140.

6. Perumalraj R. Single-stage Antimicrobial and Crease Proof Finishing of Cotton Materials. Journal of Industrial Textiles 2013; 42(4): 376391.

7. Huang G. Nettle (Urtica cannabina L) Fibre, Properties and Spinning Practice. Journal of the Textile Institute 2005; 96(1): 11-15.

8. Karthik T, Rathinamoorthy R and Murugan R. Enhancement of Wrinkle Recovery Angle of Cotton Fabric Using Titric Acid Crosslinking Agent with Nano-TiO2 As A Co-catalyst. Journal of Industrial Textiles 2012; 42(2): 99-117.

9. Refaie R. Polymeric Additives for Improving Performance Properties of Cotton Fabric Crosslinked with 1,2,3,4 Butane Tetra Carboxylic Acid. In: 8th Arab International Conference on Polymer Science \& Technology, 2005.

10. Fouda MMG, El Shafei A, Sharaf S and Hebeish A. Microwave Curing for Producing Cotton Fabrics with Easy Care and Antibacterial Properties. Carbohydrate Polymers 2009; 77, 651-655.

11. Reddy N and Yang Y. Biofibers from Agricultural by Products for Industrial Applications. Trends in Biotechnology 2005; 23(1): 22-27

12. John MJ and Thomas S. Biofibres and Biocomposites. Carbohydrate Polymers 2008; 71: 343-364.

13. Bodros E and Baley C. Study of The Tensile Properties of Stinging Nettle Fibres (Urtica dioica). Materials Letters 2008; 62: 2143-2145.

14. Bacci L, Lonardo SD, Albanese L, Mastromei G and Perito B. Effect of Different Extraction Methods on Fiber Quality of Nettle (Urtica dioica L.). Textile Research Journal 2010; 81(8): 827-837.

15. Kurban M, Yavaş A and Avinç OO. Nettle Fibers and Their properties. Electronic Journal of Textile Technologies 2011; 5(1): 84 106.

16. Zhou W, Yang CQ and Lickfield GC. Mechanical Strength of Durable Press Finished Cotton Fabric Part V: Poly (vinyl alcohol) As An Additive to Improve Fabric Abrasion Resistance. Journal of Applied Polymer Science 2004; 91: 3940-3946.

17. Sauperl O and Stana-Kleinschek K. Differences Between Cotton and Viscose Fibers Crosslinked with BTCA. Textile Research Journal 2010; 80(4): 383-392

18. Dehabadi VA, Buschmann HJ and Gutmann JS. Study of Easy Care and Biostatic Properties of Finished Cotton Fabric with Polyamino Carboxylic Acids. The Journal of the Textile Institute 2013; 104(4): 414-418.

19. Shekarriz S, Cohen P, Carr CM, Mitchell R and Jones C. Surface Chemical Analysis of 1,2,3,4-butanetetracarboxylic Acid Modified Cotton. Journal of Materials Science 2003; 38: 2945-2951.

20. Zhou LM, Yeung KW, Yuen CWM and Zhou X. Characterization of Ramie Yarn Treated with Sodium Hydroxide and Crosslinked by 1,2,3,4-butanetetracarboxylic acid. Journal of Applied Polymer Science 2004; 91: 1857-1864. this article. The author(s) also declared that this article is original, was prepared in accordance with international publication and research ethics, and ethical commitee permission or any special permission is not required.
21. Hebeish A, Hashem M, Abdel-Rahman A and El-Hilw ZH. Improving Easy Care Nonformaldehyde Finishing Performance Using Polycarboxylic Acids via Precationization of Cotton Fabric. Journal of Applied Polymer Science 2006; 100: 2697-2704.

22. Li W, Xu X, Chen S, Zhou X, Li L, Chen D and Wang X. Esterification Crosslinking Structures of Rayon Fibers with 1,2,3,4butanetetracarboxylic Acid and Their Water-responsive Properties. Carbohydrate Polymers 2008; 71: 574-582.

23. Mostafa KhM, Samarkandy AR and El-Sanabary AA. Using Persulfate Oxidized Chitosan As A Novel Additives in Easy-care Finishing for Cotton Textiles. Polymer-Plastics Technology and Engineering 2009; 48(2): 130-135.

24. Dehabadi VA, Buschmann H-J and Gutmann JS. Durable Press Finishing of Cotton Fabrics with Polyamino Carboxylic Acids. Carbohydrate Polymers 2012; 89: 558-563.

25. Vasluianu E, Popescu V, Grigoriu A, Forna NC and Sandu I Comparative Study Concerning The FTIR Analysis and The Performances of Chitosan-based Wrinkle-Proofing Agents. Rev Chim 2013; 64(10): 1104-1115.

26. Bajaj P. Finishing of Textile Materials. Journal of Applied Polymer Science 2002; 83: 631-659.

27. El-tahlawy KF, El-bendary MA, Elhendawy AG and Hudson SM. The Antimicrobial Activity of Cotton Fabrics Treated with Different Crosslinking Agents and Chitosan. Carbohydrate Polymers 2005; 60: 421-430.

28. Dehabadi VA, Buschmann H-J and Gutmann JS. Durable Press Finishing of Cotton Fabrics: An overview. Textile Research Journal 2013; 83(18): 1974-1995.

29. Oktem T. Surface Treatment of Cotton Fabrics with Chitosan. Coloration Technology 2003; 119: 241-246.

30. Aly AS, Hashem A and Hussein SS. Utilization of Chitosan Citrate As Crease-resistant and Antimicrobial Finishing Agent for Cotton Fabric. Indian Journal of Fibre \& Textile Research 2004; 29: 218-222.

31. Montazer $\mathbf{M}$ and Afjeh MG. Simultaneous X-linking and Antimicrobial Finishing of Cotton Fabric. Journal of Applied Polymer Science 2007; 103: 178-185.

32. Demir A, Arik B, Ozdogan E and Seventekin N. A New Application Method of Chitosan for Improved Antimicrobial Activity on Wool Fabrics Pretreated by Different Ways. Fibers and Polymers 2010; 11(3): 351-356.

33. Hebeish A, Abdel-Mohdy FA, Fouda MMG, Elsaid Z, Essam S, Tammam GH and Drees EA. Green Synthesis of Easy Care and Antimicrobial Cotton Fabrics. Carbohydrate Polymers 2011; 86: 1684-1691.

34. Bhuiyan MAR, Shaid A, Bashar MM, Haque P and Hannan MA. A Novel Approach of Dyeing Jute Fiber with Reactive Dye After Treating with Chitosan. Open Journal of Organic Polymer Materials 2013; 3: 87-91.

35. Viju S and Thilagavathi G. Effect of Chitosan Coating on The Characteristics of Silk-Braided Sutures. Journal of Industrial Textiles 2013; 42(3): 256-268

36. Reddy KM, Feris K, Bell J, Wingett DG, Hanley C, Punnoose A. Selective toxicity of zinc oxide nanoparticles to prokaryotic and eukaryotic systems. Appl Phys Lett. 2007;90:2139021-3

37. Huh AJ, Kwon YJ. "Nanoantibiotics": a new paradigm for treating infectious diseases using nanomaterials in the antibiotics resistant era. J Controll Release. 2011;156:128-45. 
38. Dastjerdi R, Montazer M. A review on the application of inorganic nano-structured materials in the modification of textiles: focus on antimicrobial properties. Colloids Surf B Biointerfaces. 2010;79:5-18.

39. Stoimenov PK, Zaikovski V, Klabunde KJ. Novel halogen and interhalogen adducts of nanoscale magnesium oxide. J Am Chem Soc. 2003;125:12907-13

40. Nohynek GJ, Lademann J, Ribaud C, Roberts MS. Grey goo on the skin? Nanotechnology, cosmetic and sunscreen safety. Crit Rev Toxicol. 2007;37:251-77.

41. Applerot G, Lellouche J, Perkas N, Nitzan Y, Gedanken A, Banin E. $\mathrm{ZnO}$ nanoparticle-coated surfaces inhibit bacterial biofilm formation and increase antibiotic susceptibility. Rsc Adv. 2012;2:2314

42. Blecher K, Nasir A, Friedman A. The growing role of nanotechnology in combating infectious disease. Virulence. 2011; 2: 395-401.

43. Chen, J.; Zhu, J.; Cho, H.-H.; Cui, K.; Li, F.; Zhou, X.; Rogers, J.; Wong, S.; Huang, X. Differential Cytotoxicity of Metal Oxide Nanoparticles. J. Exp. Nanosci. 2008, 3, 321-328.

44. Brayner, R.; Ferrari-Iliou, R.; Brivois, N.; Djediat, S.; Benedetti, M. F.; Fievet, F. Toxicological Impact Studies Based on Escherichia' Coli Bacteria in Ultrafine $\mathrm{ZnO}$ Nanoparticles Colloidal Medium. Nano Lett. 2006, 6, 866-870.
45. Herman, D.; Walz, J. Y. Effects of Metal Oxide Nanoparticles on the Stability of Dispersions of Weakly Charged Colloids. Langmuir 2015, 31, 4844-4852

46. Li, C.-C.; Chang, M.-H. Colloidal Stability of CuO Nanoparticles in Alkanes via Oleate Modifications. Mater. Lett. 2004, 58, 3903-3907

47. Koruyucu A, Pakolpakçıl A, Öztürk, O. Investigation of the Possibilities of Gaining Antibacterial Properties with Metal Oxide Particles and Cotton Fabrics. NKUBAP.00.17.AR.12.13 proje, 2015.

48. JIS L 1902:2008. Testing for antimicrobial activity and efficacy on textile products. JAFET/JSA from Japanese Industrial Standards

49. Koruyucu A,Erdal B, Kurç M, Gülen D. Improvement of Washing Strength of Cotton Fabrics with Anti-bacterial Properties with Copper and Zinc Oxide Particles. NKUBAP.06.GA.16.064 proje, 2018.

50. Yang CQ (1991) Characterizing ester crosslinkages in cotton cellulose with FTIR photoacoustic spectroscopy. Textile Res J 61(5):298-305.

51. Wei WS, Yang CQ (1999) Predicting the performance of durable press finished cotton fabric with infrared spectroscopy.Textile Res J 69(2):145-151

52. Choi HM, Welch CM, Morris NM (1994) Nonphosphorus catalysts for formaldehyde-free DP finishing of cotton with 1, 2, 3, 4butanetetracarboxylic acid. Textile Res J 64(9):501-507 